\title{
ANALYSIS OF HUNGARIAN RURAL DISTRICTS IN THE ASPECT OF ENDOGENOUS DEVELOPMENT
}

Gábor Bodnár, assistant lecturer

Szent István University Faculty of Economics, Agriculture and Health Studies

Address: $\quad 33$ Bajza utca, Békéscsaba, H-5600

Phone: $\quad+36-66-524-700 / 1009$

E-mail: $\quad$ bodnar.gabor@gk.szie.hu 


\title{
ANALYSIS OF HUNGARIAN RURAL DISTRICTS IN THE ASPECT OF ENDOGENOUS DEVELOPMENT
}

Keywords: Hungarian rural districts, endogenous development, principal component analysis

\begin{abstract}
:
In my paper I analyse the development differences of Hungarian rural districts. The theoretical basis of the analysis is given by the theory of endogenous development and its indicators respectively. Recently, endogenous development has gained emphasis, and it has many approaches on which specific indicators may provide the fundamental basis of territorial development. The application of common elements may help to configure a framework which is suitable for carrying out measurements.

After reviewing the literature regarding the topic, I aim at measuring the quantitative elements of endogenous development to which the reintroduction of districts serve as a novel framework. With the help of method of principal analysis I created two principals. First one, called private fixed capital, shows a strong territorial concentration of highly developed areas, and we can recognize easily the lagging districts too. The second principal component, called human capital, demonstrates the demographical possibilities of rural territories. It reveals a very various picture and we can face two contradictory processes at the same time.
\end{abstract}

\section{INTRODUCTION}

Endogenous development is a rather complex concept, especially when related to endogenous growth. This makes sense, because social welfare has several different interpretation and can be seized by qualitative measures in contrast to growth with its typically quantitative features. This, of course, does not mean that my work should not include quantitative analysis.

As van Leeuwen et al (2009) mention, in the last few decades, major economic changes have taken place both in rural and urban territories, which process resulted in the decay of the relevance of traditional rural activities with regard to rural areas.

However, the situation has changed by today - it is a huge advance that we can talk about brand new or highly appreciated functions of rural territories. Although it is true that the more complex approach of rural areas gained higher emphasis, the diversity of functions and multifunctional approach were uniformly conceived and developed in the OECD (2006) „New Rural Paradigm” for the first time.

Consequently, paradigm change in the approach of rural territories, and enhanced emphasis on endogeneous development together throw a new light upon the possibilities of rural development and growth.

In the first part of the paper I introduce the main processes of Hungarian countryside. Then I review the theory of endogenous development, with the help of international literature of the subject. I highlight the different components of the various approaches, and in the analytic part of the essay I work with private fixed capital and human capital as 
basic fundaments of regional endogenous development. The two created principal components include the indicators which can able to describe the two earlier mentioned types of capital. After the description of data reduction the two principal components will be analysed.

\section{SHORT REVIEW OF MAIN PROCESSES OF HUNGARIAN COUNTRYSIDE}

As Enyedi (2012) explaines in relation to rural-urban dichotomy and their inequalities, neither the social nor the economic changes, having taken place since the regime change, provide favourable circumstances for equalization.

Such a major shift necessarily has significant impacts: as Buday-Sántha (2010) notes, rural territories have undergone polarization in the last two decades. He also mentions that the rising tendency of unfavourable processes in the field of economy and society is of concern. Along with the closing down of manufacturing plants and liquidating rural industry, the countryside was deprived of its economic support. Villages in rural territories lost their local economic intellectuals, former leaders of the sometime manufacturing plants who would have been able to implement locally required developments.

In relation to the countryside, the role of agriculture has to be mentioned, which was characterized by uncertainty and convulsion due to sudden changes after the economic transition (Benet 2006).

Buday-Sántha (2010) refers to that development can be observed in those regions only that have been able to integrate into urban economy which, however, most of the rural territories did not manage to reach. Also, advantage of development resources can only be perceived in infrastructural improvements, while there seem to be no relevant agricultural achievements. Consequently, local governments without own income are struggling in such circumstances.

What is more, a significant polarization process evolved after the transition and remained peculiar according to Beluszky és Sikos T. (2007). They also mention that such a process has several dimensions, for instance, one affecting the labour market, or another having impact on the composition of the local community.

\section{THEORY OF ENDOGENOUS DEVELOPMENT}

The author of this article agrees with the general idea that while growth induces quantitative change, development results in qualitative change. Based on traditional 
economics, development is generally interpreted as economic development (Farkas 2002). However, it is essential to note, as Lengyel (2012) does, that economic development encompasses economic growth, because beside basic economic indicators it is advisable to take some other economic features into account as well.

In relation to regional economic development, Capello and Nijkamp (2011), besides others, give the examples of healthy living environment, access to social facilities and high-quality education.

When discussing regional economic development, Stimson et al. (2011) differentiate quantitative and qualitative attributes. The following factors are all of concern while carrying out measurements and monitoring regional economic processes such as changing wealth and income levels, employment levels, generating creative capital, social and financial equity, or sustainable development.

Benko (1997) dates back the appearance of endogenous development to the end of the 1980's though it is a fact that then he talked about industrial and urban territories.

The tone of regional development theory and its focus has shifted from exogenous factors to a focus on endogenous factors during the past few decades (Stimson et al. 2011).

As Capello (2011, p. 14.) defines that endogenous development „....is fundamentally dependent on a concentrated organization of the territory, embedded in which is a socioeconomic and cultural system whose components determine the success of the local economy: entrepreneurial ability, local production factors (labour and capital), relational skills of local actors generating cumulative knowledge-acquisition - and, moreover, a decision-making capacity which enables local economic and social actors to guide the development process, support it when undergoing change and innovation, and enrich it with the external information and knowledge required to harness it to the general process of growth, and to the social, technological and cultural transformation of the world economy".

Stimson et al. (2011) point out a further change in the focus of processes towards the principles of sustainable development in regional development and planning in the last two decades.

As it is described in an ESPON (2011) paper, most of the theoretical literature on intangible assets comes from the fields of regional development or entrepreneurship, and mainly places emphasis on urban territories. 
The document (ESPON 2011) mentions two attempts which adapt these ideas in rural policy context. The first one is the assets-based approach to development (Braithewaite 2009), the second one is an examination of Camagni's (2008) concept of "territorial capital" by Courtney et al. (2010). I summarise Braithwaite's approach hereunder.

Braithwaite (2009) uses a seven-element capital framework which corresponds to categorising assets (Table 1). The importance of this approach is that the framework includes political and cultural capital, which are particularly important in a rural context.

Braithwait $(2009$, p. 2) describes the usefulness of the framework as ,...it can act as a 'prompt' to remind rural residents of the attributes of their area and of the potential they have for development".

In my opinion, the essence of the approach and the seven assets of Braithwait is in accord with other mainstream researches of endogenous development, at the same time, his explanation of these assets in rural context is remarkable anyway.

When working with the framework of the numerous types of capital we can talk about the appearance of territorial capital as a special approach of endogenous development. This concept originally occurred in so called ,policy” documents (AEIDL 1999, OECD 2001, EC 2005). Thus it has been formulated in the OECD (2001) document with regard to territorial capital that the territorial dimension has a determining effect on profitability and competitiveness of economic activities.

However, a more scientific and sophisticated approach of the subject has emerged recently which belongs to Camagni $(2008,2009)$.

Camagni $(2008,2009)$ has worked out a framework which incorporates all tools that are important in relation to regional development. His approach provides the possibility of a homogeneous, theoretical framework, which is suitable for describing present regional processes, and also might be useful when making prognoses.

In this perspective, according to definitive approach territorial capital itself is a set of assets which determine a given territory's character (Camagni 2008).

As we shall see, territorial capital with its approach and being structured in a framework goes far beyond the traditional economic conceptions applied both in the case of growth and development measurements (Lengyel 2012). 
Table 1 Presence of various kinds of capital

\begin{tabular}{|l|c|c|c|c|c|}
\hline Capital & $\begin{array}{c}\text { Stimson et al. } \\
(\mathbf{2 0 1 1})\end{array}$ & $\begin{array}{c}\text { Braithwaite } \\
(\mathbf{2 0 0 9 )}\end{array}$ & $\begin{array}{c}\text { AEIDL } \\
(\mathbf{1 9 9 9})\end{array}$ & $\begin{array}{c}\text { Camagni } \\
\mathbf{( 2 0 0 8 )}\end{array}$ & $\begin{array}{c}\text { ETC } \\
(\mathbf{2 0 0 7})\end{array}$ \\
\hline $\begin{array}{l}\text { private fixed } \\
\text { capital }\end{array}$ & $\mathrm{x}$ & $\mathrm{x}$ & $\mathrm{x}$ & $\mathrm{x}$ & $\mathrm{x}$ \\
\hline human capital & $\mathrm{x}$ & $\mathrm{x}$ & $\mathrm{x}$ & $\mathrm{x}$ & $\mathrm{x}$ \\
\hline social capital & $\mathrm{x}$ & $\mathrm{x}$ & & $\mathrm{x}$ & $\mathrm{x}$ \\
\hline creative capital & $\mathrm{x}$ & & $\mathrm{x}$ & $\mathrm{x}$ & \\
\hline $\begin{array}{l}\text { ecological/natural } \\
\text { capital }\end{array}$ & $\mathrm{x}$ & $\mathrm{x}$ & & $\mathrm{x}$ & $\mathrm{x}$ \\
\hline built capital & & $\mathrm{x}$ & $\mathrm{x}$ & $\mathrm{x}$ & $\mathrm{x}$ \\
\hline cultural capital & & $\mathrm{x}$ & $\mathrm{x}$ & $\mathrm{x}$ & $\mathrm{x}$ \\
\hline political capital & & $\mathrm{x}$ & $\mathrm{x}$ & $\mathrm{x}$ & \\
\hline business firms & & & $\mathrm{x}$ & $\mathrm{x}$ & \\
\hline external relations & & & $\mathrm{x}$ & $\mathrm{x}$ & \\
\hline image & & & $\mathrm{x}$ & & \\
\hline
\end{tabular}

Source: own construction

We can see the same elements in each approach of endogenous development many times (Figure 1). The classical, Marxian capital appears in all cases of examined theories. Human capital is also present everywhere and social, creative, ecological, built and cultural kinds of capital are important as well. These types of capital mean the fundamentals of my principal analysis in chapter 5, which quantitative analysis was made among rural districts of Hungary. These sorts of capital are acting important part of all or almost all investigated approaches.

\section{DELIMITATION OF RURAL DISTRICTS}

OECD (2010, p. 3) uses only one indicator to make the distinction between urban and rural settlements, classifying "local units" as rural if their population density is below 150 inhabitants per square kilometre.

Csatári (2001) believed that OECD 150 people $/ \mathrm{km} 2$ limit should be lowered to 120 in order to comply with the peculiarities of Hungarian population density and territorial networks (Figure 1). So becomes possible to categorize Hungarian minor territorial units by the urban/rural index, i.e. determine the weight of residents at territories with density under and above 120 people $/ \mathrm{km}^{2}$.

Urban/rural index considers 104 territorial units rural, the extent of such feature is varying, of course. However, this is a widely accepted method; there are one or another cities in each rural areas, which, in many cases, anything but rural. In any case, by this 
method $61 \%$ of Hungary is rural area with a population of more than 3 million. In the paper I adapt this method and its results. Further on I create a quantitative analysis which leans on this method.

Figure 1 Rural districts of Hungary

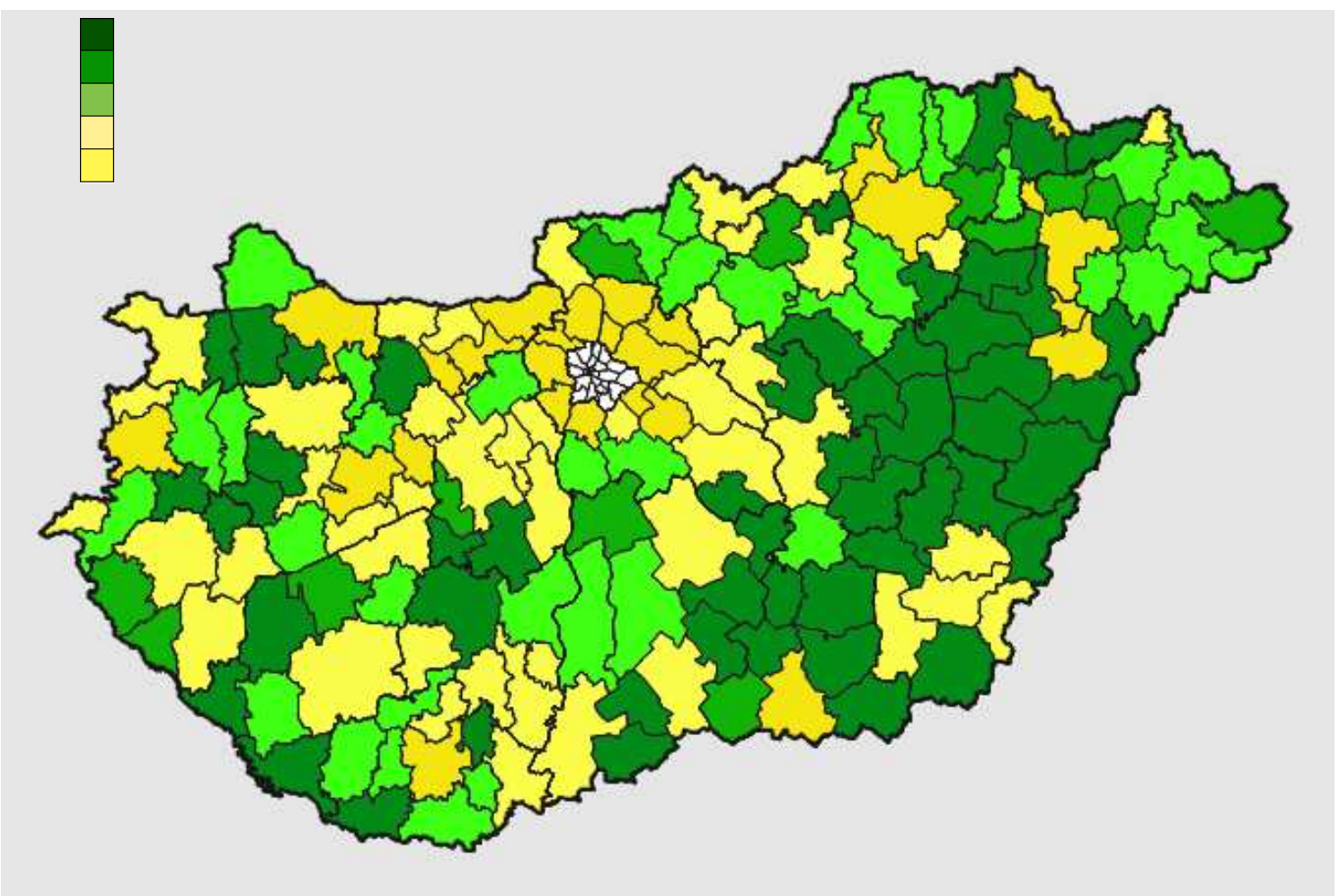

Source: own construction based on CSO data

\section{METHODS}

I used the method of principal component analysis to process the indicators. This dimension reductive method is typically used when greater number of determinants is at play. This method has few prerequisites concerning the items to be used, one being correlation between the data. I carried out each of these analyses and the results permitted the use of principal analysis.

For the analysis, I used statistical software called SPSS which is widely recognised according to the number of works that examine its methodology (Ketskeméty - Izsó 2005; Lengyel - Katona 1999; Nemes Nagy 2005, 2007). The hereunder mentioned 11 series of data have become two principals, making it possible to group the districts according to their factor value. Then I used EuroOffice 2012 for the depiction of the results. To categorize the districts could simply be sorted into five groups based upon their factor values. 
Hence, based on these results, I obtained an extensive picture concerning the classical capital and human qualities of Hungarian rural territory. I obtained data from the Central Statistical Office database. During the selection of relevant data, I took the Hungarian census 2011. This present study involves 11 indicators from the Hungarian census 2011 and from CSO basic data of districts.

KMO and Bartlett's test consists of several experiments, but in this case the measure of sampling adequacy and the significance are essential. The measure of sampling adequacy is satisfactory over value 0.5 , I reached 0.808 . Significance has to be under the 0,05 value, in my analysis 0.000 . I consider both ones to be adequate.

The communalities reveal the extent of how replaceable each variable is, which were considered in the model (initials), by the new, reduced variables (extraction). The lowest value is also above sixty percent $(61.6 \%)$ which is satisfying.

And the total variance explained is close to eighty percent $(78.2 \%)$.

Table 2 Rotated component matrix

\begin{tabular}{|l|r|r|}
\hline & \multicolumn{2}{|c|}{ Component } \\
\cline { 2 - 3 } & \multicolumn{1}{|c|}{1} & 2 \\
\hline $\begin{array}{l}\text { The ratio of registered jobseekers compared to the population in } \\
\text { employment age, \%, 2011 }\end{array}$ &,- 297 \\
\hline $\begin{array}{l}\text { Registered jobseekers longer than a year compared to the population in } \\
\text { employment age, \%, 2011 }\end{array}$ &, 827 &,- 210 \\
\hline $\begin{array}{l}\text { Gross income serving as basis of the personal income tax per tax-payer, } \\
\text { thousand Ft, 2011 }\end{array}$ &,- 785 &,- 017 \\
\hline $\begin{array}{l}\text { Average number of recipients of regular social assistance per thousand } \\
\text { inhabitants, 2011 }\end{array}$ &, 863 &,- 039 \\
\hline Passenger cars per thousand inhabitants, 2011 &,- 782 &, 324 \\
\hline Number of employees per one hundred households, 2011 &,- 883 &,- 203 \\
\hline Mortality rate (deaths per 1000 inhabitants), pcs, 2011 &, 234 &, 758 \\
\hline The ratio of the population older than 65 to the whole, \%, 2011 &,- 124 &, 934 \\
\hline Elderly population per hundred children, 2011 &,- 354 &, 897 \\
\hline Number of persons per hundred households, 2011 &, 012 &,- 875 \\
\hline Total children per hundred families, 2011 &, 334 &,- 845 \\
\hline
\end{tabular}

Source: own construction

As we can see in table 2, the two principal components can be classified well. The indicators in each component have high explanation and those are able are able to provide a possible solution for the questions. 


\section{RESULTS}

The first principal component represents the six series of data becoming private fixed capital principal component or we can say these indicators symbolize the Marxian capital in rural districts. This component involves the series of data which suggest the access to fixed capital by direct (e.g. income-tax and automobile ownership) or indirect (e.g. employment status and benefits) ways (Figure 2).

Figure 2 Principal component of private fixed capital

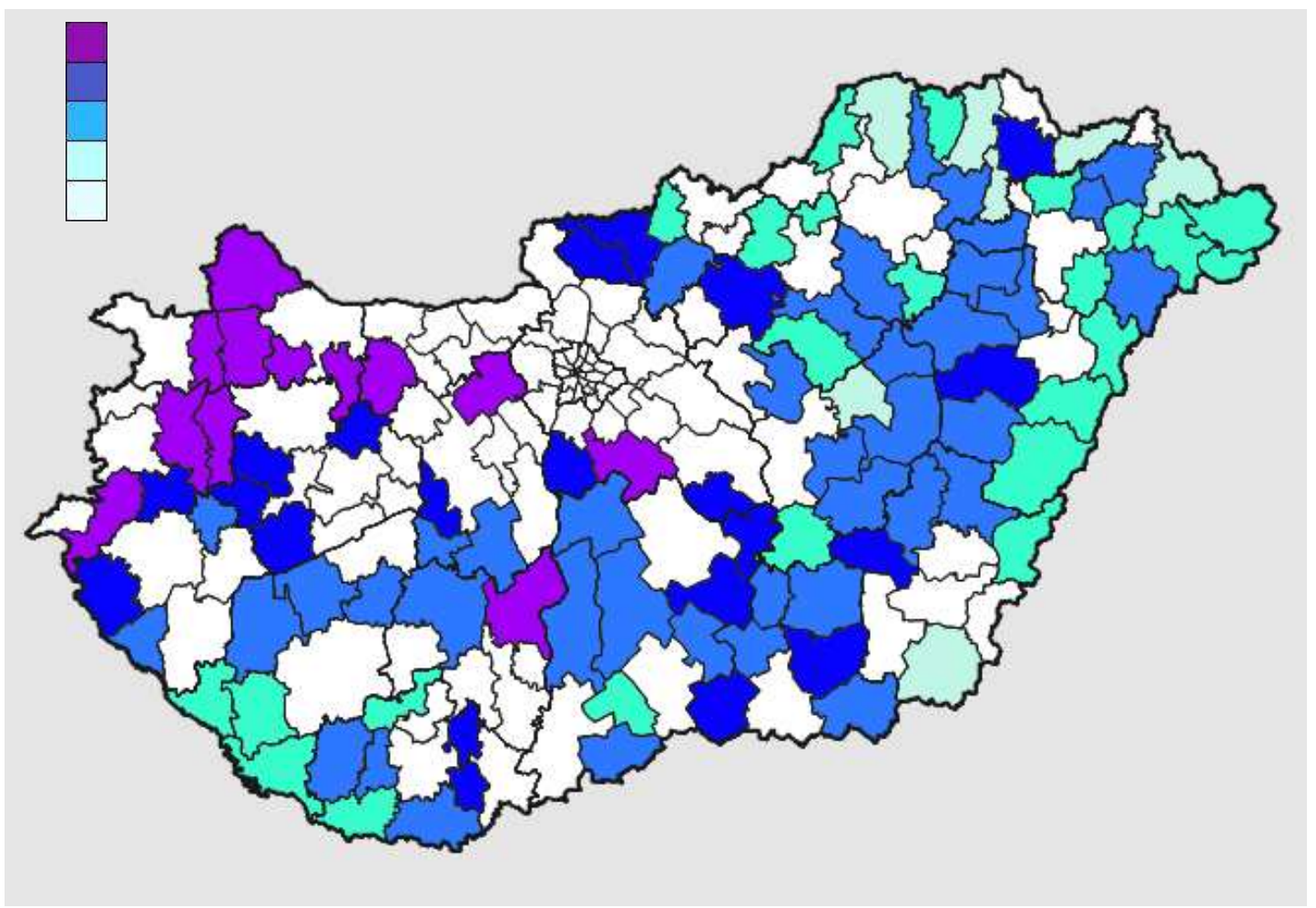

Source: Own construction based on CSO data

There are sharp differences between the most developed and the most underdeveloped territories. Aforementioned developed regions are concentrated in the north-western part of Transdanubia. We can find the district with the best figure (Mosonmagyaróvári járás) here as well. Lagging districts have a higher dispersion in the country, but they can be delimited easily as well. Many of them are located in north-eastern and eastern Hungary. There are a lot of less favoured territories near the Romanian border. But in the southern part of Transdanubia we can see underdeveloped districts too. Behind the figures we can see huge differences, e.g. the one and the half score difference between income-tax values is not rare, and the three or four times difference is also incidence by the unemployment rate. 
Figure 3 Principal component of human capital

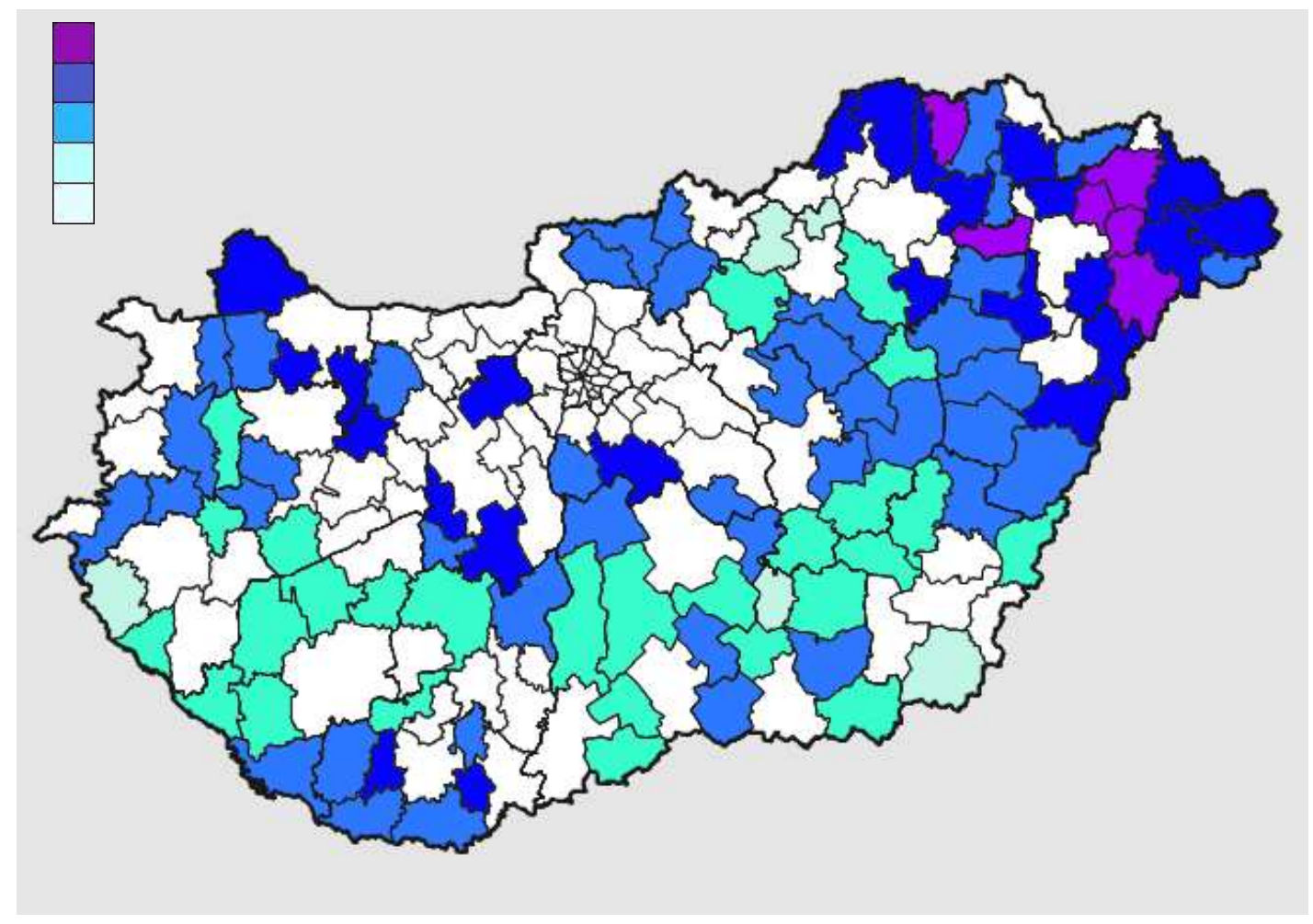

Source: Own construction based on CSO data

The principal component of human capital reveals a very different picture than the figure of previous capital. We can see districts with good values in the northern Transdanubia, but the highest values are in north-eastern Hungary (Figure 3.). As we mentioned by the private fixed capital part of the paper, these territories of the country are the wealthiest and most underdeveloped. It has to be clear that the background of the good figures are very different, but by the numbers these districts have the best demographic performance. By the indicators in these districts the number of children per hundred families is so high. This spatial structure is very unique and so difficult to describe even with a complex series of data.

The Southern Great Plain has many middle-class or lower results. This means in this case the unfavourable demographic processes, e.g. elderly and increasing population. In this territory we can see some slightly developed areas by private fixed capital with poor human capital values. 


\section{CONCLUSION}

In my paper I analyzed the topic of endogenous regional development. In the last decades we can see a shift from exogenous to endogenous development.

I reviewed which factors mean the fundamentals of each endogenous development theory, which are the roots of local development. There are a lot of similar factors in the different models, but we might see a couple of differences too. After the highlight of common points of examined models, based on these elements, I made principal analysis among the earlier delimited 104 rural districts.

The private fixed capital is concentrated in the northern part of Transdanubia. And we can see sharp differences between these part and the eastern part of the country. There is an almost continuous zone of lagging regions near the Romanian border and in north-east Hungary.

The picture of human capital reveals very different processes. Northern Transdanubia has also good performance, but north-eastern Hungary has the highest figures. But as we saw, by the fixed capital holding, these are the opposite „poles” of the country by development. In the paper as I have already explained by using quantitative analysis variant causes can result similar outcome or figures.

\section{SUMMARY}

In my paper I analyzed the development of rural districts in Hungary. The theoretic background of the essay is given by endogenous regional development. This theory has many approaches, which have the same root in common. Therefore, despite the overlaps between the key elements and capital of theories we can find differences. A sort of synthesis of these kinds of capital is thought to be important while the base of those is the framework of endogenous development can be appropriate to perform a quantitative analysis.

In the first part of the paper I review the main processes of Hungarian countryside briefly. Countryside regions are unique territorial spaces in terms of economic abilities, social features and the structure of settlements. In the last decades rural areas came through remarkable changes in whole Europe, thus Hungary as well. In case of the latter, the regime change had high importance and this has considerable significance up to this day. Hungary went through many social and economic changes and it was the reason why rural areas encountered difficulties.

Before the review of the theory of endogenous development I state that I agree with the expansively accepted opinion that growth is quantitative, development is qualitative change. Therefore, quantitative analysis is also important when measuring growth despite the fact that it is difficult to perform.

Beside defining endogenous development in my paper I compare five models and their elements. The mostly wellknown model is probably Camagni's territorial capital framework. Through the comparison it is clear that the two most common types of capital are private fixed capital and human capital. The first one can be defined as classical Marxian capital as well.

So I ventured upon to execute measurements amongst rural districts. This can be important because of the increasing importance of endogenous development in last decades. This kind of development based on local assets and the utilization of those.

The framework of analysis is the reintoduced system of districts in 2013. In this framework with the help of urban/rural index we can easily define the characteristics of each area, which one is rural, and we can name the rate of being rural. After this delimitation we can qualify 104 districts as rural ones, with varying standard. These districts encompass two third of the territory of Hungary and more than three millions of the population. 
I analyzed this territory and I used the method of principal component analysis. By this dimension reductive method, the primarily determined eleven indicators were merged into two principal components, the private fixed one, and the human one.

The first principal component can be defined as a group of Marxian capital or the possible reach of this capital by the withdrawn indicators. In this case the analysis highlights an unambiguous territorial concentration in the northwestern part of Hungary. Almost all well developed rural districts can be found in this area. Unfortunately, the unfavoured districts can also be easily located well. Most of them are located at peripheral areas e. g. next to the Romanian border.

The second principal component symbolizes the human capital which based on demographic indicators. If we compare to first principal component this one shows a very different picture. Although Transdanubia also has quite good figures, the most outstanding districts are in the northeastern part of Hungary. As I mentioned earlier this principal component includes demographical indicators, this is the explanation. So, in this manner the best values do not mean high development definitely. To consider these territories which have high potential is more proper. It is a fact as well that behind the best figures there are contradictory social processes, what depends on location. In the case of eastern districts we can find poverty, on the other hand the western districts are is relatively welfare.

\section{SUMMARY IN HUNGARIAN}

\section{A MAGYAR VIDÉKIES JÁRÁSOK VIZSGÁLATA AZ ENDOGÉN FEJLŐDÉS ASPEKTUSÁBÓL}

Munkámban a magyarországi vidékies járások fejlettségét vizsgáltam. A munka elméleti hátterét az endogén regionális fejlődés szakirodalma adta. Magának az elméletnek, bár gyökere értelemszerüen ugyanaz, mégis számos megközelítése létezik. Így az elméletek által kulcstényezőkként kezelt elemek, illetve tőkék között az átfedések ellenére is akadnak eltérések. Ezen tőkék egyfajta szintetizálását azért is tartom fontosnak, mert ezekre alapozva az endogén fejlődés megfelelő keretrendszert biztosíthat kvantitatív elemzések elvégzésére.

Munkám elején röviden áttekintem a magyar vidék meghatározó folyamatait. Maga a vidék egyfajta sajátos települési, gazdasági és társadalmi környezettel bíró, a városiastól jellegzetesen eltérö tér. Az elmúlt évtizedek során jelentős változáson mentek keresztül a vidéki területek egész Európában, így Magyarországon is. Utóbbi esetében a rendszerváltás jelentős és sokszor mai napig maghatározó jelentőségü esemény volt. Számos társadalmi-gazdasági változás lezajlott, melyeknek a vidék sokszor elszenvedője volt.

Az endogén fejlődés elméletére áttérve, annak ismertetése előtt leírom, hogy egyetértve a széles körben elfogadott véleménnyel, a növekedést mennyiségi, a fejlődést minőségi változásnak tartom. Így bár utóbbi esetében is egyértelmüen helye van a kvantitatív elemzéseknek, azok elvégzése igen nehéz.

Az endogén fejlődés definiálása mellett munkámban összehasonlításra kerül öt modell, illetve azok tőketényezői. A modellek közül talán legismertebb Camagni területi tőke keretrendszere. Az összehasonlítás következtében láthatóvá válik, hogy a két legáltalánosabb a termelő tőke és a humán tőke. Előbbit értelmezhetjük a klasszikus, marxi értelemben vett tőkeként is.

Így e két tényező mentén próbáltam méréseket elvégezni a vidékies járások körében. Ami már csak azért is fontos lehet, mert az endogén fejlődés, vagyis a helyi adottságok széleskörü kiaknázása a vidéki terek esetében is előtérbe került az elmúlt időszakban.

A mérés kereteit a Magyarországon 2013. elején ismét kialakított járási rendszer képezi, melyek körében az urbanitás/ruralitás indexszel könnyen meghatározhatóak, hogy mely területek, milyen mértékben vidékiesek az országban. Az így létrejött lehatárolás szerint 104 járás minősül vidékiesnek, eltérő mértékben. Ezen járások az ország területének közel kétharmadát foglalják magukba és a népesség tekintetében több mint három millió ember lakóhelyét jelentik.

E területegységek körében végeztem mérést. Az elemzés módszertanát illetően a főkomponens elemzésre támaszkodtam, így ezzel a dimenziócsökkentési eljárásnak a segítségével a felhasznált tizenegy indikátorból létrejött a termelö tőkét és a humán tőkét szimbolizáló fökomponens.

Az első főkomponens, az abba bekerült indikátorok alapján, értelmezhető a marxi értelemben vett tőke, illetve az ahhoz való lehetséges hozzájutás csoportjaként. Ebben az esetében a vizsgálat eredményei egyértelmü térbeli tömörülést mutatnak az ország északnyugati részében. Gyakorlatilag az összes, ilyen téren fejlettnek nevezhetö vidékies járás itt található. Sajnos a lemaradó, illetve fejletlen területegységek elhelyezkedése is viszonylag jól meghatározható. Azok többnyire az ország peremvidékein, így például a román határ mentén fekszenek.

A második főkomponens a humán tőkét szemlélteti demográfiai mutatók alapján. Ebben az esetben igen eltérő kép rajzolódik ki az első főkomponens eredményeihez képest. Bár a Dunántúl északi részén elhelyezkedő járások ezúttal is elég jó értékekkel rendelkeznek, a leginkább kimagasló eredményekkel az ország északkeleti járásai rendelkeznek. Ezt magyarázza, hogy a fökomponensben, mint korábban említettem, demográfiai mutatók szerepelnek. Így ezen fökomponens esetében a legjobb értékek nem feltétlenül jelentenek egyben magas fejlettséget is. Helyesebb úgy megközelíteni ezen értékeket, mint magas potenciállal rendelkező térségeket. Az is tény, hogy a legjobb értékek mögött, függően, hogy a járás Magyarország keleti, vagy nyugati felén helyezkedik 
el, ellentétes társadalmi folyamatok állnak, előbbi esetben a mélyszegénység, míg utóbbi esetben a viszonylagos jólét.

\section{REFERENCES}

AEIDL (1999). Territorial competitiveness - Creating a territorial development strategy in light of the LEADER experience, Part 1. LEADER European Observatory AEIDL, Bruxelles, Belgium. http://ec.europa.eu/agriculture/rur/leader2/ruralen/biblio/compet/competitivite.pdf. Downloaded: 1st June, 2013.

Beluszky P., \& Sikos T. T. (2007). Változó falvaink. MTA Társadalomkutató Központ, Budapest.

Benet I. (2006). 60 years of Hungarian agricultural policy (1945-2004). In: Benet, I. (ed): Agricultural transition and rural development: Some experiences from Finland, Hungary and Poland. Institute of Economics Hungarian Academy of Sciences Károly Róbert College, Gyöngyös - University of Pécs, Faculty of Economics, Budapest - Gyöngyös - Pécs, pp. 17-28.

Benko, G. (1997). A regionális fejlődés útjai: globálistól a lokálisig. Tér és Társadalom, 2 , pp. 1-16.

Braithwaite, K. (2009). Building on What You Have Got - A Guide to Optimising Assets. Carnegie UK Trust, Dunfermline, UK.

Buday-Sántha A. (2010). Vidékfejlesztés. Vitaanyag. Tér és Társadalom, 1, pp. 215-221.

Camagni, R. (2008). Regional competitiveness: towards a concept of territorial capital. In Capello, R. - Camagni, R. - Chizzolini, B. - Fratesi U. (eds): Modelling regional scenarios for the enlarged Europe. Springer-Verlag, Berlin, pp. 33-47.

Camagni, R. (2009). Territorial capital and regional development. In Capello, R. Nijkamp, P. (eds): Handbook of regional growth and development theories. Edward Elgar, Cheltenham, pp. 118-132.

Capello, R. (2011). Location, Regional Growth and Local Development Theories. Aestimum, 1, pp. 1-25.

Capello, R., \& Nijkamp, P. (2011). Regional growth and development theories revisited. In Stimson, R. - Stough, R. R. - Nijkamp. P. (eds): Endogenous Regional Development. Perspectives, Measurement and Empirical Investigation. Edward Elgar, Cheltenham, UK - Northampton, MA, USA, pp. 301-324.

Courtney, P., Talbot, H., \& Skuras, D. (2010). Establishing the Potential for Territorial Cooperation. EDORA, Working Paper 27. Final Draft: 16 September 2010., http://www.nordregio.se/Global/Research/EDORA/EDORA_2.31.pdf. Downloaded: 21st April, 2013.

Csatári, B. (2001). A vidék földrajzi kérdései. In: Dormány, G., Kovács, F., Péti, M., Rakonczai, J. (eds.): A földrajz eredményei az új évezred küszöbén. SZTE TTK Természeti Földrajzi és Geoinformatikai Tanszék, Szeged, pp. 1-9. http://geography.hu/mfk2001/cikkek/Csatari.pdf. Downloaded: 8th October, 2010.

EC (2005). Scoping Document and Summary of Political Messages for an Assessment of the Territorial State and Perspectives of the European Union: Towards a Stronger European Territorial Cohesion in the Light of the Lisbon and Gothenburg Ambitions. European Commission. http://www.eu2005.lu/en/actualites/documents_travail/2005/05/20regio/Min_DOC_1 fin.pdf. Downloaded: 4th October, 2012.

Enyedi Gy. (2012). Falvak és városok. In Mezei C., - Bakucz M. (szerk.): Agrárátalakulás, környezeti változások és regionális fejlödés. Tanulmányok BudaySántha Attila 70. születésnapjára. Pécsi Tudományegyetem Közgazdaságtudományi Kar, Pécs, pp. 29-34. 
ESPON (2011). EDORA - European Development Opportunities for Rural Areas. Applied Research 2013/1/2. ESPON \& UHI Millennium Institute, http://www.espon.eu/export/sites/default/Documents/Projects/AppliedResearch/EDO RA/EDORA_Final_Report_Parts_A_and_B-maps_corrected_06-02-2012.pdf. Downloaded: 20th April, 2013.

ETC (2007). Learning Endogenous Development - Building on Bio-cultural Diversity. ETC Foundation - Compas, Bourton on Dunsmore, Rugby, Warwickshire, UK.

Farkas T. (2002). Vidékfejlesztés a fejlődéselméletek és a fejlesztési koncepciók tükrében. Tér és Társadalom, 1, pp. 41-57.

Ketskeméty L., \& Izsó L. (2005). Bevezetés az SPSS programrendszerbe. ELTE Eötvös Kiadó, Budapest.

Lengyel I. (2012). Regionális növekedés, fejlődés, területi tőke és versenyképesség. In Bajmócy Z. - Lengyel I. - Málovics Gy. (eds): Regionális innovációs képesség, versenyképesség és fenntarthatóság. JATEPress, Szeged, pp. 151-174.

Lengyel I., \& Katona T. (szerk.) (1999). Statisztikai ismerettár. JATEPress, Szeged.

Nemes Nagy J. (szerk.) (2005). Regionális elemzési módszerek. ELTE Regionális Földrajz Tanszék, Budapest.

Nemes Nagy J. (2007). Kvantativ társadalmi térelemzési eszközök a mai regionális tudományban. Tér és társadalom, 1, pp. 1-19.

OECD (2001). Territorial Outlook. OECD, Paris, France.

OECD (2006). The New Rural Paradigm. Policies and Governance. Paris, France.

OECD (2010). Regional typology. http://www.oecd.org/dataoecd/35/62/42392595.pdf. Downloaded: $1^{\text {st }}$ August, 2011.

Stimson, R., Stough, R. R., \& Nijkamp. P. (2011). Endogenous Regional Development. In Stimson, R. - Stough, R. R. - Nijkamp. P. (szerk): Endogenous Regional

Development. Perspectives, Measurement and Empirical Investigation. Edward Elgar, Cheltenham, UK - Northampton, MA, USA, pp. 1-19.

van Leeuwen, E. S., Rietveld, P., \& Nijkamp, P. (2009). Multifunctional Towns: Effects of New Retail Developments in Rural Areas. In Brouwer, F. - van der Heide, C. M. (eds): Multifunctional Rural Land Management. Earthscan, London, UK, pp. 297317. 